\title{
STUDY ON CHANGES IN GLOMERULAR FILTRATION RATE (GFR) AND ITS RELATION TO SERUM INORGANIC PHOSPHATE LEVEL IN ADVANCED STAGES OF CHRONIC KIDNEY DISEASE
}

\author{
SAHA GC ${ }^{1}$, MUSTAFA E $^{2}$, SALEHIN $\mathrm{M}^{3}$, ALAM T ${ }^{4}$, AKHTARUZZAMAN $\mathrm{M}^{5}$, MAHMUD A ${ }^{6}$
}

\begin{abstract}
Background: Glomerular filtration rate (GFR) reflects renal function and in chronic kidney disease (CKD) stage 3-5, there is electrolyte imbalance which is reflected by changes in serum creatinine and phosphate level. The aim of this study was to determine GFR in advanced stages of CKD and its relation with serum creatinine and serum inorganic phosphate.
\end{abstract}

Methods: This was a cross sectional study which was done in Rajshahi Medical College, Rajshahi. A total of 120 patients were taken. Among them ninety were with advanced stages of CKD and thirty were as control group.

Results: Mean GFR in healthy control was $104.953 \pm 16.663 \mathrm{ml} / \mathrm{min}$., mean GFR in CKD3 group was 36.256 5 5.582, in CKD4 group was $21.142 \pm 5.420 \mathrm{ml} / \mathrm{min}$. and in CKD5 group was $10.304 \pm 2.694 \mathrm{ml} / \mathrm{min}$. Mean serum creatinine in healthy control was $0.936 \pm 0.116 \mathrm{mg} / \mathrm{dl}$ and $2.226 \pm 0.272,3.698 \pm 0.915 \& 6.906 \pm 2.439 \mathrm{mg} / \mathrm{dl}$ in CKD3, CKD4 \& CKD5 respectively. While, the mean serum inorganic phosphate level in healthy control group was $1.23 \pm 0.17 \mathrm{mmol} / \mathrm{L}$, and $1.79 \pm 0.11,2.09 \pm 0.27 \& 3.04 \pm 0.33 \mathrm{mmol} / \mathrm{L}$ in CKD3, CKD4 \& CKD5 respectively.

Conclusion: Serum creatinine and phosphate levels are increased with the severity of CKD.

Key words: Chronic kidney disease (CKD), glomerular filtration rate (GFR), serum creatinine, serum phosphate.

J Dhaka Med Coll. 2014; 23(1) : 37-40.

\section{Introduction:}

Chronic kidney disease (CKD) also known as chronic renal disease is a progressive loss in renal function over a period of months or years. CKD is identified by the measurement of serum creatinine, as higher levels of creatinine indicates a lower glomerular filtration rate (GFR) ${ }^{1}$. The progression of CKD occurs in five different stages in which there are gradual changes of GFR, serum creatinine and serum inorganic phosphate ${ }^{2}$.

In an advanced stage of chronic renal failure, renal osteodystrophy/renal bone disease will occur. If we start calcium supplementation and phosphate binder to the patients of chronic kidney disease, it will be helpful to prevent renal bone disease. In advance stage of CKD i.e. stage 4 or 5 GFR is significantly reduced. These stage 4 or stage 5 of CKD patient cannot be properly hydrated because their body is swollen, urine output very low. But before measurement of GFR or creatinine clearance, patient should be properly hydrated otherwise adequate urine output should not occur. Therefore, GFR or creatinine clearance test cannot be accurately done in advanced stage (4 or 5) of CKD patient. Alternately Estimation using Cockcroft-Gault formula should be adapted in advanced stage of CKD patient ${ }^{3}$. Hence, the present study was carried out to

1. Dr. Gobinda Chandra Saha, Department of Physiology, Sher-e-Bangla Medical College, Barisal.

2. Dr. Ekramul Mustafa, Department of Physiology, Dhaka Medical College, Dhaka.

3. Dr. Masood Salehin, Department of Physiology, Dhaka Medical College, Dhaka.

4. Dr. T Alam, Department of Physiology, Rajshahi Medical College, Rajshahi.

5. Dr. M Akhtaruzzaman, Department of Biochemistry, Shaheed Suhrawardy Medical College, Dhaka.

6. Dr. Asif Mahmud, Department of Surgery, Sir Salimullah Medical College \& Mitford Hospital, Dhaka.

Correspondence : Dr. Gobinda Chandra Saha, Department of Physiology, Sher-e-Bangla Medical College, Barisal. 
estimate GFR in advanced stage (3-5) of CKD patient as well as healthy subject and correlate with serum calcium and inorganic phosphate level. The objective of this study was to determine GFR in advanced stages of CKD and its relation with serum creatinine and serum inorganic phosphate.

\section{Methods:}

This study was carried out in the Department of Physiology, Rajshahi Medical College, Rajshahi. In this study a total number of 120 patients were included from Department of Nephrology, Rajshahi Medical College Hospital, Rajshahi. This study was carried out on 90 patients (55 male, 35 female) of advanced stages (stages 3-5) of CKD, with age ranged from 20-65 years. 30 apparently healthy persons of same age ranges were taken as controls. Patients were divided into 3 groups - CKD3, CKD4 \& CKD5 on the basis of their eGFR values from KDOQI clinical practice guidelines stratification (Table-I) ${ }^{2}$.

\section{Table-I}

Distribution of patients in different groups according to the stages of CKD

\begin{tabular}{lcc}
\hline Stages & $\begin{array}{c}\text { GFR } \\
\left(\mathrm{ml} / \mathrm{min} / 1.73 \mathrm{~m}^{2}\right)\end{array}$ & $\begin{array}{c}\text { Number of } \\
\text { patients }\end{array}$ \\
\hline CKD 3 & $30-59$ & 30 \\
CKD 4 & $15-29$ & 30 \\
CKD 5 & $<15$ & 30 \\
\hline
\end{tabular}

Laboratory tests were done as follows:

1. Serum creatinine by alkaline picrate method,

2. Estimation of GFR by using Cockcroft-Gault formula, and
3. Serum inorganic phosphate by analyzer (Screen Master-3000).

\section{Results:}

Mean GFR in healthy control was $104.953 \pm 16.663 \mathrm{ml} / \mathrm{min}$., mean GFR in CKD3 group was $36.256 \pm 5.582$, in CKD4 group was $21.142 \pm 5.420 \mathrm{ml} / \mathrm{min}$. and in CKD5 group was $10.304 \pm 2.694 \mathrm{ml} / \mathrm{min}$. Mean serum creatinine in healthy control was $0.936 \pm 0.116 \mathrm{mg} / \mathrm{dl}$ and $2.226 \pm 0.272,3.698 \pm 0.915 \& 6.906 \pm 2.439 \mathrm{mg} /$ d1 in CKD3, CKD4 \& CKD5 respectively. While, the mean serum inorganic phosphate level in healthy control group was $1.23 \pm 0.17 \mathrm{mmol} / \mathrm{L}$, and $1.79 \pm 0.11,2.09 \pm 0.27 \& 3.04 \pm 0.33 \mathrm{mmol} / \mathrm{L}$ in CKD3, CKD4 \& CKD5 respectively (Table-II).

When GFR was compared between groups, control group was significantly higher than CKD3 group $(\mathrm{P}<0.05)$, CKD 3 group was significantly higher than CKD4 group $(\mathrm{P}<0.05)$ and CKD4 group was significantly higher than CKD5 group $(\mathrm{P}<0.05)$. As serum creatinine level compared between groups, control group was found significantly lower than CKD3 group $(\mathrm{P}<0.05)$, CKD3 group was significantly lower than CKD4 group $(\mathrm{P}<0.05)$ and $\mathrm{CKD} 4$ group was significantly lower than CKD5 group $(\mathrm{P}<0.05)$ (Fig. 1). When serum inorganic phosphate levels were compared between the groups, control group was significantly lower than CKD3 group $(\mathrm{P}<0.05)$, CKD3 group was significantly lower than CKD4 group $(\mathrm{P}<0.05)$ and CKD4 group was significantly lower than CKD5 group $(\mathrm{P}<0.05)$ (Fig. 2).

In this study, GFR has a negative correlation with both the serum creatinine $(\mathrm{r}=-0.791, \mathrm{P}$ $<0.01$ ) (Fig. 3) and serum inorganic phosphate $(r=-0.891, \mathrm{P}<0.01)$ (Fig. 4).

Table-II

Different biochemical parameters in various groups

\begin{tabular}{lcccc}
\hline & $\begin{array}{c}\text { Control group } \\
(\mathrm{n}=30) \\
\text { Mean } \pm \text { SD }\end{array}$ & $\begin{array}{c}\text { CKD3 group } \\
(\mathrm{n}=30) \\
\text { Mean } \pm \mathrm{SD}\end{array}$ & $\begin{array}{c}\text { CKD4 group } \\
(\mathrm{n}=30) \\
\text { Mean } \pm \text { SD }\end{array}$ & $\begin{array}{c}\text { CKD5 group } \\
(\mathrm{n}=30) \\
\text { Mean } \pm \mathrm{SD}\end{array}$ \\
\hline Serum Creatinine & $0.936 \pm 0.116$ & $2.226 \pm 0.272$ & $3.698 \pm 0.915$ & $6.906 \pm 2.439$ \\
(Normal range0.6-1.3 mg/d1) & & & & \\
GFR(Normal range120-125 ml/min) & $104.99 \pm 16.66$ & $36.25 \pm 5.58$ & $21.14 \pm 5.42$ & $10.30 \pm 2.69$ \\
Serum Inorganic Phosphate & $1.23 \pm 0.17$ & $1.79 \pm 0.11$ & $2.09 \pm 0.27$ & $3.04 \pm 0.33$ \\
(Normal range0.8-1.4 mmol/L) & & & & \\
\hline
\end{tabular}




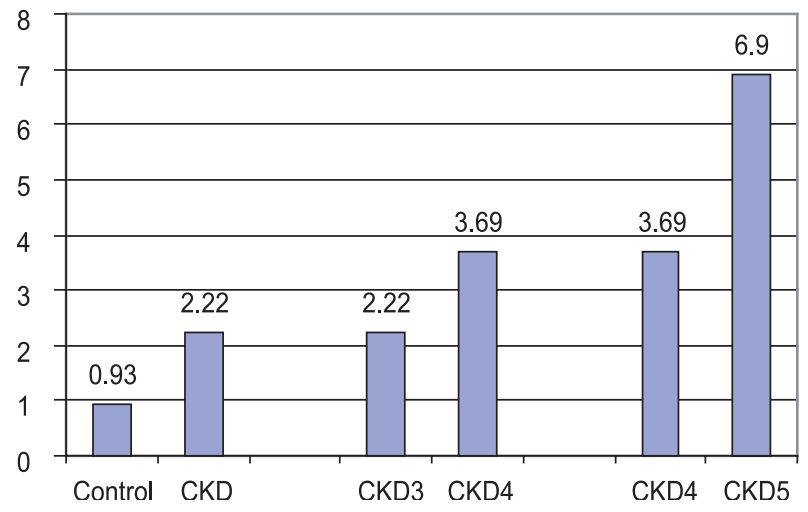

Fig. 1: Comparison of serum creatinine among different groups.

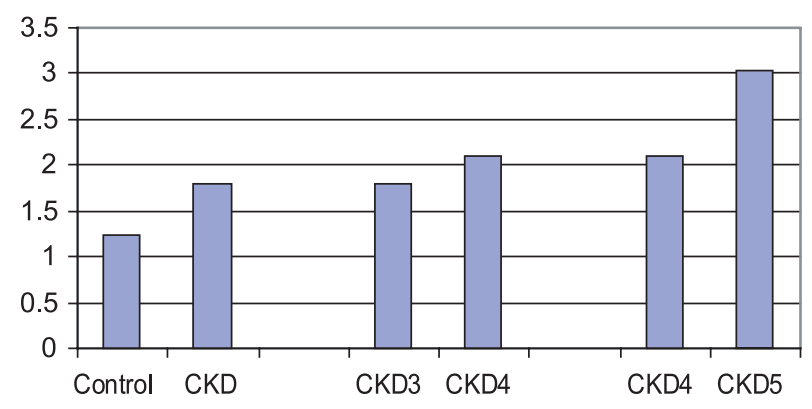

Fig. 2: Comparison of serum inorganic phosphate among different groups.

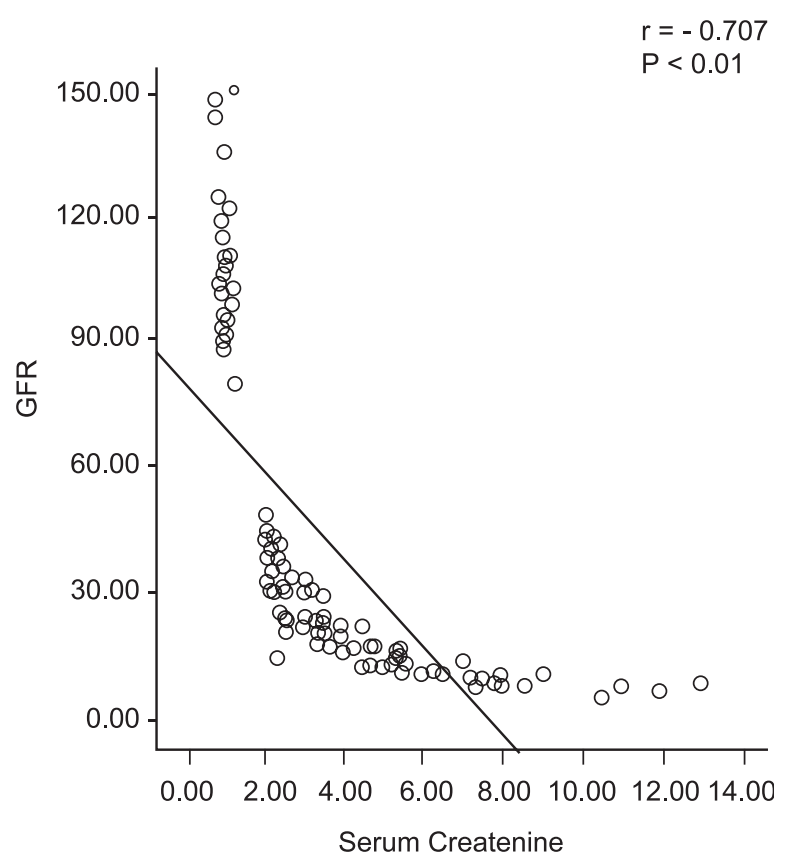

Fig. 3: Correlation between GFR and serum creatinine.

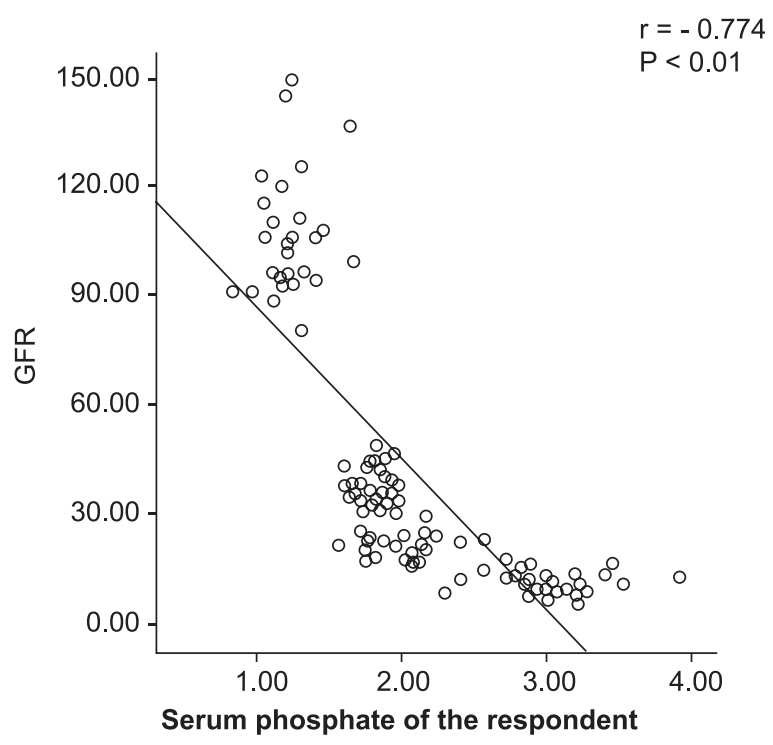

Fig. 4: Correlation between GFR and serum inorganic phosphate.

\section{Discussion:}

Pitts et al (1988) ${ }^{5}$ divided the patients into (i) Mild renal failure $\left(\mathrm{C}_{\mathrm{Cr}} 40-90 \mathrm{ml} / \mathrm{min}\right)$ (ii) Moderate renal failure $\left(\mathrm{C}_{\mathrm{Cr}} 20-40 \mathrm{ml} / \mathrm{min}\right)$ and (iii) End-stage renal failure $\left(\mathrm{C}_{\mathrm{Cr}}<20 \mathrm{ml} / \mathrm{min}\right)$. Pitts et al. found a significant higher value of s. inorganic phosphate in end stage renal failure group $\left(\mathrm{C}_{\mathrm{Cr}}<20 \mathrm{ml} / \mathrm{min}\right)$ than control group $(\mathrm{P}<0.01)$.

In our study, s. inorganic phosphate level of CKD5 group was significantly higher than that of control\& CKD3 group. Hence, our findings were consistent with that of Pitts et al. ${ }^{5}$.

It had been originally proposed that hypocalcaemia triggers hyperparathyroidism in early renal failure by Slatopolsky et al. $(1971)^{6}$. Bricker $(1972)^{7}$ suggested that, phosphate retention and altered vitamin D metabolism contribute to the genesis of hypocalcaemia in uremia.

According to Drueke $(1995)^{8}$, calcitriol deficiency and phosphate retention together with hypocalcaemia are the main factors involved in the pathogenesis of secondary hyperparathyroidism. Phosphate retention is considered to be a key pathogenic factor, as it decreases calcitriol production and interferes with calcaemic effect of $\mathrm{PTH}^{9,10}$. However, in this study, estimation of PTH was not done. 
From the present work, it may be concluded that hyperphosphataemia occurs in the advanced stages of CKD patients and was directly related with the degree of renal failure.

\section{References:}

1. National Kidney Foundation. Special Bulletin. 2002.

2. KDOQI clinical practice guidelines stratification. Available from: http://www.kidney.org/ professionals/kdoqi/guidelines_ckd/ p4_class_g1.htm [Accessed on January 10, 2013].

3. Sladen RN, Endo E, Harrison T. 2-hour versus 22 -hours creatinine clearance in critically ill patients. Anesthesiology 1987; 67:1013-6.

4. Morrison B. Assessment of renal function. Med Intern 1986; 2(11): 1258-64.

5. Pitts TO, Piraino BH, Mitro R, Chen TC, Segre GV, Greenberg A, et al. Hyperparathyroidism and 1,25-dihydroxy vitamin B deficiency in mild, moderate and severe renal failure, J Clin Endocrin Metab 1988; 67: 876-81.

6. Slatopolsky E, Caglar S, Pennell JP, Taggart DD, Canterbury JM, Reiss E, et al. On the pathogenesis of hyperparathyroidism in chronic experimental renal insufficiency in the dog. J Clin Invest 1971; 50: 492 .

7. Bricker NS. On the pathogenesis of the uremia state: An exposition of the "trade-off hypothesis". N Engl J Med 1972; 286: 1093.

8. Drueke T. The pathogenesis of parathyroid gland hyperplasia in chronic renal failure [Nephrology Forum]. Kidney Int 1995; 48: 259-72.

9. Rodriguez M, Felsenfeld AJ, Llach F. Calcaemic response to parathyroid hormone in renal failure: Role of calcitriol and the effect of parathyroidectomy. Kidney Int 1991; 40: 1063-8.

10. Bover J, Rodriguez M, Trinad P, Jara A, Martinez ME, Machad OL, et al. Factors in the development of secondary hyperparathyroidism during graded renal failure in the rats. Kidney Int 1994; 45: 953-60. 